International Journal of Advanced Chemistry, $8(1)(2020) 175-179$
International Journal of Advanced Chemistry
WPC
Website: www.sciencepubco.com/index.php/IJAC
Research paper

\title{
The nutritional potentials and the fatty acid profile of the seed and seed oil of Caesalpinia bonducella
}

\author{
Adeyeye Adeniyi $^{1 *}$, Sulaiman Wasiu Kayode ${ }^{1}$, Akinyode Olakunle Abayomi ${ }^{1}$ \\ ${ }^{1}$ Department of Chemical Sciences, Oduduwa University, Ipetumodu, PMB 5533, Ile-Ife, Osun State, Nigeria \\ *Corresponding author E-mail: niyade2016@gmail.com
}

\begin{abstract}
The physicochemical properties of the seed and fatty acid profile of the seed oil of Caesalpinia bonducella were analyzed in this study, using standard methods of the Association of Official Analytical Chemists (AOAC). The proximate composition was found as follows: Moisture (3.24\%), crude fat $(41.76 \%)$, crude protein $(28.63 \%)$, crude fibre $(4.35 \%)$, ash content $(2.94 \%)$ and carbohydrate $(19.08 \%)$. The total unsaturated fatty acids $(57.36 \%)$ was more abundant than the total saturated ones $(42.68 \%)$. The seed oil had a high level of linoleic acid $(28.15 \%)$, followed by oleic $(18.41 \%)$, stearic $(13.83 \%)$ and palmitic $(13.56 \%)$. Other fatty acids had less than $10 \%$ each. There was a high level of unsaturation $(57.36 \%)$ with oleic and linoleic acids dominating all other fatty acids with a total of $46.56 \%$. The percentage of essential fatty acids (linoleic \& linolenic acids) (32.96\%) was also high at about $1 / 3$ of the total oil content. The total poly-unsaturated fatty acids $(36.99 \%)$ was higher than those of mono-unsaturated $(20.37 \%)$. The high level of poly-unsaturated fatty acids in the oil sample is an advantage as these are essential components of the diet of man. The good total unsaturated/saturated (or P/S) ratio of the oil, (i.e.1.344), makes it to be very nutritionally useful if adopted for domestic purposes.
\end{abstract}

Keywords: Caesalpinia Bonducella Seeds; Caesalpinia Bonducella Seed Oil; Physicochemical Properties; Fatty Acid Profile; Total Unsaturated/Total Saturated $(P / S)$ Index.

\section{Introduction}

Caesalpinia bonduc (L.)Roxb (Syn. Caesalpinia bonducella (L.) Fleming, Syn, Caesalpinia crista (Linn.), belongs to the family Febaceae/caesalpiniaceae. It is a prickly shrub widely distributed all over the world especially in India, Srilanka and Nigeria. The seed is called "ayo" or "sereyo" by the Yoruba people of Southwestern Nigeria. It is a leguminous plant and an extensive climber with branches spread out, having straight and hooked prickles. The leaves are around 30 to $60 \mathrm{~cm}$ long and have short prickly petioles. Small yellow flowers are produced in supra and terminal auxillary racemes on top. The pods have short stalks and are covered with prickles which have one or two seeds. Each seed is grey colored with a smooth, shining surface. The seeds look like eyeballs and are used for relaxation games in the Southwest of Nigeria. They are also used for Bodhi beads in China (Li et al. 2014).

Caesalpinia bonducella plant has played a significant role in maintaining human health and improving the quality of human life for thousands of years and has served the human race as valuable components of medicine, seasonings, beverages, cosmetics and dyes. Every part of the plant (root, seed, leaves and flowers) is useful for therapeutic purposes and the root, stem, leaves, bark, seeds and nuts have been used for one medicinal purpose or the other. The seed is claimed to be styptic, purgative, anthelmintic and controls inflammations, and is useful for colic, hydrocele, skin diseases, leprosy and palsy. It has also been found useful for the treatment of headache and skin eruptions. (Moon et al. 2010; Singh \& Raghav 2012).

Caesalpinia bonduc nut is popular for its therapeutic properties in many regions in Asia and the tropical islands of the Pacific Ocean, where the different parts of the plant are used for similar purposes as in different African nations. The seeds have been shown chemically to possess anti-bacterial, anti-fungal, febrifuge, anti-viral, purgative, hypoglycaemic, hypocholesterolemic and anti-cancer properties. The seeds also possess soothing properties and are employed for calming stomach problems. The ointment, made from the powdered seeds with castor oil, can be applied externally in hydrocele and orchi. The oil from the seeds is also said to soften the skin and remove pimples (Moon et al. 2010; Sigh \& Raghav 2012).

Caesalpinia bonducella is antiperiodidic, a febrifuge and anthelmintic. A powder of the roasted pods has been used as a substitute for quinine for malaria. The root bark is used to treat fever, intestinal worms, tumours, amenorrhoea, cough and for removing the placenta after childbirth. The leaves and their juice are used similarly and also traditionally for elephantiasis and smallpox, disorders of the liver and to destroy perspiration odour. An ethanolic extract of the root and stem exhibited activity against the vaccinia virus. A hot water extract of the leaves is used to prevent abortion and as a uterine tonic immediately after delivery, while the boiled leaves provide a gargle for sore throat. The wood was used in the olden days as a dye which is similar to haematoxylin. Essentially, the bitter extract from the seeds, which is known as poor man's quinine, is used for the treatment of malaria. The oil from the seeds is used to treat rheumatism (Moon et al. 2010; Sigh \& Raghav 2012). 
In spite of all these important worldwide uses, C. bonducella seeds have attracted less attention compared to the leaves and roots, and much less has been reported about the seeds' fatty acid composition. This report therefore looked into the proximate composition and fatty acid contents of C. bonducella as available in Nigeria, in order to elucidate the composition and its usefulness to the daily needs of man.

\section{Materials and method}

\subsection{Sample collection and preparation}

Samples of the seeds of C. bunducella were collected from the plant, located in a vegetation adjacent the campus of this Institution, Ife Ibadan Road, Ipetumodu, Osun State, Nigeria. The seeds were removed from their pods and pulverized using an electric blender, ready for analysis.

\subsection{Sample treatment}

\subsubsection{Proximate analysis}

Moisture, ash, crude fat and crude fibre were determined in accordance with the official methods of the Association of Official Analytical Chemists (AOAC 2012). Moisture content of each sample was determined by oven drying of $25 \mathrm{~g}$ of sample to a constant weight at $105^{\circ} \mathrm{C}$. Crude protein content was determined by Kjeldahl method using 6.25 as the conversion constant after the determination of its nitrogen. Crude fat content was determined by Soxhlet method using hexane as solvent. The ash content was determined gravimetrically after ignition at $550^{\circ} \mathrm{C}$. Carbohydrate content was calculated by difference. All analyses were carried out in triplicates.

\subsubsection{Fatty acid analysis}

The fatty acids were converted to their methyl esters and the esters analysed using a PYE Unicam 304 gas chromatograph fitted with a flame ionization detector and PYE Unicam computing integrator. Helium was used as the carrier gas. The column initial temperature was $150^{\circ} \mathrm{C}$ rising at $5^{\circ} \mathrm{C}$ min- 1 to a final temperature of $220^{\circ} \mathrm{C}$. The injection port and detector temperatures were maintained at $220^{\circ} \mathrm{C}$ and $250^{\circ} \mathrm{C}$ respectively. The peaks were identified by comparing with peaks of standard fatty acid methyl esters under the same operating conditions.

\section{Results and discussion}

\subsection{Proximate composition}

The proximate composition of Caesalpinia bonducella seed is shown in Table 1. The seed had a low moisture content of $3.24 \%$, a value that is lower than the values for Cola nitida, Cola acuminata and Garcinia cola $(12.85,13.25$ and $15.20 \%$ respectively) (Adeyeye et al. 2017), and that of African walnut (Tetracarpidium conophorum , 19.20\% ) (Ekwe \& Ihemeje 2013). The low moisture content of the seed is the reason for its long shelf life, as this prevents its early spoilage. The plant seed is a good source of oil (41.76\%). The seed had a much higher oil content than those of Cola nitida, Cola acuminata and Garcinia kola with values of 9.15, $10.75 \& 8.40 \%$ respectively (Adeyeye et al. 2017), and that of Dioclea reflexa (10.65\%) (Ajayi 2014), but lower than that of Entada gigas (60.4\%) (Ogungbenle \& Omodara 4014).Apart from domestic purposes, the oil might be useful in cosmetic industries and in the manufacture of margarine.

The protein content of the seed was $28.63 \%$. This value is higher than those of Hexalobus crispiflorus (7.11\%), Clitandra togolana $(10.81 \%)$ and Dioclea reflexa (13.81\%), (Akoja \& Amoo 2011) and those reported for Cola nitida, Cola acuminata and Garcinia kola (8.75, 9.65 and 6.45\% respectively), (Adeyeye et. al. 2017). It is a little above that of Dioclea reflexa (26.00\%) reported by Ajayi (2014). Protein is a significant component of food as a source of amino acids. It also plays a part in the organoleptic properties of food (Orech et. at. 2005). It is needed for proper functioning of essential body processes such as water balancing, nutrient transport and muscle contractions, and it is also required for the formation of enzymes and hormones. In addition, it aids in the formation of antibodies that enable the body to fight infection (Brosnan 2003). It is an essential food component needed in our bodies to repair, regulate and protect itself. On the other hand, protein deficiency causes growth retardation, muscle wasting, oedema, abnormal swelling of the belly etc (Granner et. al. 1999). On the other hand, protein deficiency causes growth retardation, muscle wasting, oedema, abnormal swelling of the belly etc (Granner et. al. 1999). The appreciable amount of protein in the seed sample shows that it can be used as a protein source for man.

Table1: Proximate Composition of Caesalpina Bonducella Seed

\begin{tabular}{ll}
\hline Parameter & Composition $(\%)^{*}$ \\
\hline Crude protein & $28.63 \pm 1.25$ \\
Crude fat & $41.76 \pm 1.45$ \\
Crude fibre & $4.35 \pm 0.64$ \\
Crude ash & $2.94 \pm 0.55$ \\
Moisture & $3.24 \pm 1.52$ \\
Carbohydrate & $19.08 \pm 1.75$ \\
Gross energy $(\mathrm{kJ})$ & $425.23 \pm 2.75$ \\
\hline
\end{tabular}

*Average of three determinations.

The plant seed had an ash content of $2.94 \%$. This is lower than $9.17 \%$ reported for Dioclea reflexa seed (Ajayi 2014) and $3.55 \%$ for Andrographis paniculata (Adeyeye et al. 2018), but in the range of $2.1-4.4 \%$ reported for some legumes (Aremu et. al. 2006). The low ash content is reflective of its low mineral content. The fibre content of the seed was $4.35 \%$. The value is higher than $3.40 \%$ reported for edible Dioclea reflexa (Ajayi \& Adefioye 2012), but lower than found in Cola nitida (6.45\%), C. acuminata (5.50\%) and Gircinia cola (6.85\%) (Adeyeye et al. 2017) and 9.25\% in Dioclea reflexa (Ajayi 2014). Dietary fibre helps to lower the risk of coronary heart diseases, hypertension, diabetes, colon and breast cancer, piles and appendicitis (Omale \& Ugwu 2011). Fibre is useful for maintaining 
bulk motility and increasing intestinal peristalsis by surface extension of the food in the intestinal tract. It is necessary for a healthy condition, curing of nutritional disorders and for food digestion. (Pereira et al. 2004).

The carbohydrate content of $19.08 \%$ is higher than those found for Terminalia catapa (16.02\%) (Nzikou et al. 2010), Entada gigas (13.9\%) (Ogungbenle \& Omodara 2014) and unripe plantain (4.8\%) but lower than that of ripe plantain (39.66\%) (Wordu \& Akusu 2018), those of C. nitida, C. acuminata and Gircinia kola, $(60.65,58.25 \& 68.55 \%$ respectively) (Adeyeye et al. 2017) and kidney bean (40.0\%) (Olaofe et al. 2010). The low carbohydrate content of the seed means that it would not be a good source of energy for feed formulations.

\subsection{Fatty acid profile}

Table 2 presents the fatty acid profile of C. bonducella seed oil. Linoleic acid (28.15\%) was the most abundant fatty acid, followed by oleic $(18.41 \%)$, stearic $(13.83 \%)$ and palmitic acid (13.56\%). Others had less than $10 \%$ concentration each in the oil sample.

Table 2: Fatty Acid Composition of Caesalpinia Bonducella Seed Oil

\begin{tabular}{|c|c|}
\hline Fatty acid & Percentage \\
\hline Caproic - C6:0 & 0.36 \\
\hline Caprylic-C8:0 & 1.24 \\
\hline Capric-C10:0 & 2.09 \\
\hline Lauric-C12:0 & 6.39 \\
\hline Myristic-C14:0 & 2.92 \\
\hline Palmitic-C16:0 & 13.56 \\
\hline Palmitoleic-C16:1 & 1.38 \\
\hline Margaric $-\mathrm{C} 17: 0$ & 1.64 \\
\hline Stearic-C18:0 & 13.83 \\
\hline Oleic $-\mathrm{C} 18: 1$ & 18.41 \\
\hline Linoleic $-\mathrm{C} 18: 2$ & 28.15 \\
\hline Linolenic $-\mathrm{C} 18: 3$ & 4.81 \\
\hline Arachidonic - C20:4 & 3.76 \\
\hline Behenic - C22:0 & 0.301 \\
\hline Erucic-C22:1 & 0.85 \\
\hline Lignoceric - C24:0 & 0.35 \\
\hline Total saturated & 42.68 \\
\hline Total unsaturated & 57.36 \\
\hline Total mono-unsaturated & 20.37 \\
\hline Total poly-unsaturated & 36.99 \\
\hline Essential fatty acids & 32.96 \\
\hline Oleic/Linoleic ratio & 0.654 \\
\hline Linoleic acid/ $\alpha$-linolenic acid (LA/ALA) & 5.852 \\
\hline Total unsaturated/Total saturated ( $\mathrm{P} / \mathrm{S}$ index) & 1.344 \\
\hline
\end{tabular}

The content of linoleic acid (28.15\%), the most abundant fatty acid in this sample, is a bit lower than those of Treculia africana (30.0\%) and Podocarpus usambarensis (29.7\%), both from the Democratic Republic of Congo (Minzangi et al. 2011) and those in Cola nitida, Cola acuminata and Gircinia cola from Nigeria (38.62, 38.79 and $42.62 \%$ respectively) (Adeyeye et al. 2017), but higher than that for Entada gigas (19.5\%) from Nigeria (Ogungbenle \& Omodara 2014) and those of Yellow oleander (Thevetia peruviana) seeds from Kenya $(21.0-21.6 \%)$ (Shieunda 2013). Linoleic acid is one of the most important polyunsaturated fatty acids in human oil foods because of its distinct role in the prevention of heart diseases. Apart from preventing cardiovascular disorders such as coronary heart diseases and atherosclerosis, its presence in the oil also assists in preventing high blood pressure (Burkill et al. 1966). It also helps to relieve flaky or rough skin and maintain smooth and moist skin (Ariffin et al. 2009). Oleic acid, on the other hand, has a fundamental role in the prevention of cardiovascular diseases, and is very important in nervous cell construction (Nasri et. al. 2005). Its high intake also contributes to a decreased risk of coronary heart diseases caused by high cholesterol level in the blood (Cobertt 2003). The reasonable level of oleic acid in the oil, (18.41\%) is, therefore, of great importance for its role in reducing coronary heart diseases.

The high level of linoleic acid and the remarkable level of linolenic acid in the sample are of nutritional importance as these essential fatty acids cannot be synthesized in the body and have to be supplied from food we eat for their essential roles in the body. They play a natural preventive role in cardiovascular diseases and promote the reduction of both total and high density lipoprotein cholesterol. Inappropriate balance of essential fatty acids contributes to various kinds of malfunctioning while a proper balance maintains and even improves health (James et al. 2006; Adeyeye et al. 2018). For example, the deficiency of alpha-linolenic acid alters the course of brain development and perturbs the composition and physicochemical properties of brain cell membranes, neurones, oligodendrocytes, and astrocytes. This leads to physicochemical modifications, induces biochemical and physiological perturbations, and results in neurosensory and behavioural upset (Bourre 2004). Deficiency of dietary alpha-linolenic acid induces more marked abnormalities in certain cerebral structures than in others, and the frontal cortex and pituitary gland are more severely affected. These selective lesions are accompanied by behavioural disorders, more particularly affecting certain tests like habituation and adaptation to new situations (Bourre 2004). It also decreases the perception of pleasure, by slightly altering the efficacy of sensory organs and by affecting certain cerebral structures. The age-related impairment of hearing, vision and smell is due to both decreased efficacy of the parts of the brain concerned and disorders of sensory receptors, particularly of the inner ear or retina (Bourre 2004). Linolenic acid in the seed oil is also important as it is used in the biosynthesis of arachidonic acid and thus some prostaglandins (Nelson \& Cox 2005). The presence of arachidonic acid in this oil is also of dietary importance as it serves as a precursor of prostaglandin and thromboxane biosynthesis (Alozie et al. 2009). Both arachidonic acid and prostaglandins are required for cell growth and maintenance (Nelson \& Cox 2005). The linoleic acid (LA) and $\alpha$ linolenic acid (ALA) ratio of 5.852:1 fell within the WHO/FAO recommended ratio of between 5:1 and 10:1 (WHO/FAO 1994), buttressing the usefulness and nutritional importance of the seed oil.

The seed oil had higher total unsaturated fatty acids than total saturated. The ratio of total unsaturated to total saturated fatty acids (i. e. $\mathrm{P} / \mathrm{S}$ ratio) was 1.344 . This ratio determines the detrimental effects of dietary fat. The higher the P/S ratio, the more nutritionally useful the oil is. The oleic/linoleic acid $(\mathrm{O} / \mathrm{L})$ ratio of the oil was 0.654 . This value has to do with the stability of the oil for deep frying (Branch 
et al. 1990). The low value got for this seed oil may not favour its stability for this purpose. On the other hand, the high degree of unsaturation of the oil reduces its probability of aiding heart diseases (Ajewole \& Adeyeye 1991).

Caprylic and capric acids, which are present in this seed oil, make the oil useful in the commercial production of esters that are used in making perfumes. Because its chain length is short and has no difficulty in penetrating fatty cell wall membranes, caprylic acid is also good in the treatment of some bacterial infections (Nair et al. 2005). Capric acid is also used in the manufacture of lubricants, greases, rubber, dyes, plastics, food additives and pharmaceuticals (David et al. 2006). Myristic acid, a common saturated fatty acid, is used as a raw material in cosmetics production. Palmitic acid is a precursor in fatty acid synthesis. It is the first fatty acid produced during fatty acid synthesis and from which longer chain fatty acids can be synthesized (Murray et al. 2000). Palmitoleic acid plays an important role in increasing insulin sensitivity by suppressing inflammation, as well as inhibiting the destruction of insulin-secreting pancreatic beta cells, which make it useful for a diabetic patient (especially for type 2 diabetes mellitus). The low level of behenic acid in the seed oil $(0.301 \%)$ is an advantage as a high level of it in an oil may make it difficult for the digestive enzymes in man and animals (Balogun \& Fetuga 1985).

\section{Conclusion}

The proximate composition and fatty acid profile of Caesalpinia boncucella as obtained in Nigeria was reported in this study. The seed gave a higher percentage of unsaturated fatty acids compared to saturated fatty acids, and gave a good level of essential fatty acids, a value greater than $30 \%$ of the total fatty acid content of the seed. These values make the seed of good nutritional potential. By refining the oil to remove traces of in-essentials if any, the oil can serve as an alternative to other common vegetable oils for domestic and/or industrial purposes, thereby adding greater value to the seed in the market.

\section{References}

[1] Adeyeye A, Ayodele OD \& Akinnuoye GA (2017). Comparative study of the proximate and fatty acid profiles of Cola nitida, Cola acuminata and Garcinia kola. American Journal of Food Science and Nutrition 4(6), 80-84.

[2] Adeyeye A, Akinnuoye GA \& Akinyode OA (2018). Proximate Composition and Fatty Acid Profile of the Seeds of Andrographis paniculata. American Journal of Food Science and Nutrition Research 5(3), 71-75.

[3] Ajayi I A (2014). Oil Content and Fatty Acid Composition of Dioclea reflexa Seeds. IOSR Journal of Applied Chemistry (IOSR-JAC) 7(7) Ver. I., 68-73.

[4] Ajayi OB \& Adefioye A (2012). Comparative study on chemical composition, phytochemical screening and physic-chemical properties of the seeds of Dioclea reflexa. UltaChemistry 8(2), 251-264.

[5] Ajewole K \& Adeyeye A (1991). Seed oil of white star apple (Chrysophyllum albidum) - physicochemical characteristics and fatty acid composition. Journal of the Science of Food and Agriculture 54, 313-315. https://doi.org/10.1002/jsfa.2740540219.

[6] Akoja SS \& Amoo I A (2011). Proximate composition of some under-exploited leguminous crop seeds. Pakistan Journal of Nutrition, 10(2), 143146. https://doi.org/10.3923/pjn.2011.143.146.

[7] Alozie Y, Akpanabiatu MI, Umoh IB, Eyong EU \& Alozie GAO (2009). Amino acid composition of Dioscorea dumetorum varieties. Pakistan Journal of Nutrition, 8(2), 103-105. https://doi.org/10.3923/pjn.2009.103.105.

[8] AOAC (2012). Official Methods of Analysis, Association of Official Analytical Chemist, $19^{\text {th }}$ edition, Washington, D. C.

[9] Aremu MO, Olaofe O \& Akintayo TE (2006). A comparative study on the chemical and amino acid composition of some Nigerian under-utilized legume flours. Pakistan Journal of Nutrition 5(1), 34-38. https://doi.org/10.3923/pjn.2006.34.38.

[10] Ariffin AA, Bakar J, Tan CP, Rahaman RA, Karim R, \& Loi CC (2009). Essential fatty acids of pataya (dragon fruit) seed oil. Food Chemistry 114, 561-564. https://doi.org/10.1016/j.foodchem.2008.09.108

[11] Balogun AM \& Fetuga BL (1985). Fatty acid composition of seed oils of some members of the leguminosae family. Food Chemistry 17, 175-182. https://doi.org/10.1016/0308-8146(85)90066-4.

[12] Bourre JM (2004). Roles of unsaturated fatty acids (especially omega-3 fatty acids) in the brain at various ages and during ageing. J Nutr Health Aging 3: 163-174.

[13] Branch WD, Nakayama T \&Chinnan MS (1990). Fatty acid variation among U.S. runner-type peanut cultivars. Journal of the American Oil Chemists' Society 67: 591-593. https://doi.org/10.1007/BF02540772.

[14] Brosnan J (2003). Interorgan amino acid transport and its regulation. Journal of Nutrition 133, 2068-2072. https://doi.org/10.1093/jn/133.6.2068S.

[15] Burkill IH, Birtwistle W, Foxworthy F, Scrivenor J, \& Watson J (1966). A Dictionary of the Economic Products of the Malay Peninsula, Ministry of Agriculture and Co-operatives, Kuala Lumpur, Malaysia.

[16] Cobertt P. (2003). It is time for an oil change. Opportunities for high oleic vegetable oils. Information 14, $480-481$.

[17] David J, Anneken SB, Christoph R, Fieg G, Steinberner U \& Westfechtel A (2006). Fatty acids. Ullmann's Encyclopaedia of Industrial Chemistry. https://doi.org/10.1002/14356007.a10_245.pub2.

[18] Ekwe CC \& Ihemeje A (2013). Evaluation of physicochemical properties and preservation of African walnut (Tetracarpidiumconophorum). Academic Research International 4 (6), 501-512.

[19] Granner DK, Rodwell VW, Mayes PA \& Murray RK (1999) In: Harper's Biochemistry. A Lange Medical Book. 25th Edition. McGraw-Hill.

[20] James HO, Keefe J, Hussam A, Sastre A, David MS \& William SH (2006). Effect of omega-3 fatty acids on resting heart rate, heart rate recovery after exercise, and heart rate variability in men with healed myocardial infections and depressed ejection fractions. American Journal of Cardiology 97, 1127-1130. https://doi.org/10.1016/j.amjcard.2005.11.025.

[21] Kapoor. L. D., Hand of Ayurvedic Medicinal Plants. Herbal Reference Library. CRC Press. 424pages.

[22] Li, F., Li, J., Liu B., Zhuo J. \& Long, C. (2014). Seeds used for Bodhi beads in China. Journal of Ethnobiology \& Ethnomedicine, 10, 15. https://doi.org/10.1186/1746-4269-10-15.

[23] Minzangi, K., Kaaya, A. N., Kansiime, F., Tabuti, J. R. S., Samvura, B. \& Grahl-Nielsen, O. (2011). Fatty acid composition of seed oils from selected wild plants of Kahuzi-Biega National Park and surroundings, Democratic Republic of Congo. African Journal of Food Science 5(4), 219-226.

[24] Moon K, Khadabadi SS, Deokate UA \&Deore SL (2010). Caesalpinia bonducella F - An Overview. Report and Opinion 2(3): 83-90.

[25] Nair MK, Joy J, Vasudevan P, Hinckley L, Hoagland TA \& Venkitanarayanan KS (2005). Antibacterial effect of caprylic acid and monocaprylin on major bacterial mastitis pathogens. Journal of Dairy Science 88 (10), 3488-3495. https://doi.org/10.3168/jds.S0022-0302(05)73033-2.

[26] Nasri N, Khalil A, Fady B \& Triki S (2005). Fatty acids from seeds of Pinuspinea L - Composition and population profiling. Phytochemistry 66, 1729-1735. https://doi.org/10.1016/j.phytochem.2005.05.023.

[27] Nelson DC \& Cox MM (2005). Lehninger Principles of Biochemistry $\left(4^{\text {th }}\right.$ Ed.) W. H. Freeman \& Co. New York.

[28] Nzikou JM, Mvoula-Tsieri M, Pambou-Tobi NPG, Ndangui CB, Kimbonguila A, SilouTh, Linder M, Scher J \& Desobry S (2010). Proximate composition and physico-chemical characteristics of seed and seed oil from Terminalia catappa L. and the kinetic of degradation of the oil during heating. Australian Journal of Basic and Applied Science 4, 2039-2047. 
[29] Ogungbenle HN \& Omodara OP (2014). Physicochemical and fatty acid composition of nicker bean (Entada gigas) seed oil. Advances in Analytical Chemistry 4(2), 35-39.

[30] Olaofe O, Famurewa JAV \& Ekwagbere AO (2010). Chemical functional properties of kidney bean seed flour. Int. J. Chem. Sci. 3, 51-69.

[31] Omale J \& Ugwu CE (2011). Comparative studies on the protein and mineral composition of some selected Nigerian vegetables. Afri. J. Fd. Sci. 5(1), 22-25.

[32] Orech FO, Akenga T, Ochora J, Friis H \& Aagaard-Hassen J (2005). Potential toxicity of some traditional leafy vegetables consumed in Nyang'oma Division, Western Kenya. African Journal of Food, Agriculture, Nutrition and Development 5(1), Article 9, 14 pages.

[33] Pereira MA, O'Reilly E, Augustsson K, Fraser GE, Goldbourt U, Heitmann BL, etc. (2004). Dietary fibre and risk of coronary heart disease: A pooled analysis of cohort studies. Archives of International Medicine 164(4), 370-376. https://doi.org/10.1001/archinte.164.4.370.

[34] Shieunda OR (2013). Evaluation of nutritional properties of yellow Oleander (Thevetia peruviana) seeds in Kenya. Food Science and Quality Management 22: 88-94.

[35] Singh V \& Raghav K (2012). Review on pharmacological properties of Caesalpinia bonduc L. International Journal of Medicine and Aromatic Plants 2(3): 514-530.

[36] WHO/FAO (1994). Fats and oils in human nutrition. (Report of a Joint Expert Consultation). FAO Food and Nutrition Paper 57, Rome.

[37] Wordu GO \& Akusu MO (2018). Chemical mineral and anti-nutrient composition of plantain (musa paradisiacal) during ripening process. International Journal of Food Science and Nutrition 3(1), 150-153. 